3. Другая ветвь Киевского андеграунда. 2011. URL: https://antikvar.ua/drugaya-vetv-kievskogo-andegraunda/ (дата обращения: 20.11.2020).

4. Леоненко Н., Вайсберг В. Запоздалый некролог. 2011. URL: https://artukraine.com.ua/a/zapozdalyy-nekrolog/\#.X7apcGj7Q2w ， (дата обращения: 20.11.2020).

5. Петро Яковенко. Згадуючи обличчя 70-x. 2017. URL: http://www.golos.com.ua/article/296986 (дата обращения: 20.11.2020).

6. Трегуб Микола. URL: http://archive-uu.com/ua/profiles/mikolatregub/catalog/malyarstvo_Tr (дата обращения: 20.11.2020).

DOI https://doi.org/10.30525/978-9934-26-004-9-66

\title{
STAGES OF THE EXPERT STUDY OF GRAPHIC WORKS
}

\author{
Cherkashyna N. O. \\ Postgraduate Student \\ National Academy of Culture and Arts Management, \\ Chief Expert Forensic \\ Kharkiv Scientific Research Forensic Center \\ of the Ministry of Internal Affairs of Ukraine \\ Kharkiv, Ukraine
}

An expert examination is the action of a specialist aimed at establishing reliable and objective facts relating to an object of interest, with a view to establishing or confirming its veracity. In a broad sense, the concept of expertise means a certain set of specialist knowledge that allows to perform actions of a particular profile. Expert research is a complex process, the individual stages of which are interconnected and interdependent.

«Art examination is an independent type of examination during which the attribution and determination of the cultural and historical value of antiques or art objects are carried out» $[1$, p. 10]. Special recommendations on their handling, packaging, transportation and storage must be observed in the work with objects of art.

The following methods are used for expert studies:

- general (categories and laws of dialectical logic; formal cognitive methods: analysis, synthesis, generalization; induction and deduction, hypothesis; analogy and other); 
- general scientific (observation, measurement, description, experiment; comparison, modelling; reconstruction);

- special (visual, morphological, microscopic, photographic, physical, chemical, biological, mathematical, etc.).

The expert study consists of the following main stages: preliminary study, separate study, expert experiment, comparative study, evaluation of the results of the study and formulation of conclusions, presentation of the results of the expert study. The purpose of the preliminary study is to clarify the purpose of the study, to evaluate the material made available to the expert from the point of view of the adequacy of the latter for the solution of the questions posed, to form an overall picture of the facilities under study, phenomena, events and their special features; conjecture; expert study planning. The next stage is a separate study, which includes a comprehensive and complete study of the properties and features of the objects, phenomena, processes and intermediate conclusions about the suitability of the objects for identification. A comparative study consists of identifying the similarities, identities or divergences of the objects, phenomena and processes being examined. The penultimate step towards the final conclusions is a comprehensive assessment of the results of the expert study, the scientific justification of the origin of the identified signs, and the formulation of conclusions. It should be noted that, depending on the tasks to be set, the expert experiment phase may not be carried out.

The concept of attribution is closely related to the examination of artistic works. Attribution is the establishment of authorship, place and time of creation of a work. "Attribution is traditionally based on stylistic analysis and comparison with well-known works adopted as a standard for this master, time, direction» [2, p. 34]. The eye is the main tool for performing art attribution, and the database becomes the information gathered from the processing of a certain information base, supplemented by significant accumulated practical experience of the specialist.

However, there are cases of incorrect attribution of objects, when the specialist attributes the object to the work of a certain author or artist, using only stylistic analysis, and ignoring the fact that there are works of art, including fakes, the time of creation and the authorship of which correctly set «on the eye» is practically impossible. Before applying a method or instrument, the expert must understand that it is necessary to analyze which signs of the material of the monument indicate its authenticity or its falsification. The scientific and technical specialist should be able to correctly interpret the results of his or her analysis, based on knowledge of the history of the artistic materials and technologies. 
There are a number of special research techniques that are divided into two groups: potentially destructive and non-destructive methods, and also have different types of research properties. Special techniques refer to a system of defined rules, recommendations for studying specific properties and characteristics of objects.

For example, physical, chemical and physicochemical methods determine the external structure, the composition of elements and the molecular composition, the physical and chemical properties of the materials, and the qualitative and quantitative structure.

This work discusses special techniques that are most suitable for use in the graphic research. One of the physicochemical methods is emission spectral analysis, which makes it possible to determine the qualitative and quantitative composition of elements in a substance. «The photometric analysis makes it possible to carry out a quantitative analysis related to the action of electromagnetic radiation of different wavelengths on the substance» [4. p. 27]. Thus, this determines the presence of certain connections and elements. The choice of spectral analysis methods is carried out by an expert and depends on the features of the object of expertise. In some cases, «the spectral analysis provides for sampling and is potentially attributed to destructive research methods» [5, p. 94].

One of the important method of non-destructive nature is an optical method that allows to explore the surface of the product. «Paper invoices and used materials, graphic specifics and techniques are essential to the chart» [3, p. 194]. There are various ways of attracting the attention of the viewer, from the emotional influence of the poster to the invitation to a thorough «the carefully examination» of the miniature works.

The significant importance in the analysis of graphics should be given to the study of the paper on which it was drawn. The paper can be possible to examine the release time of the sheet, as it can often have filigree, which is the mark of the firm that made this paper. The morphology of all the constituent elements has a sufficiently profound content and provides information about the history and execution techniques, but it is necessary to be able to use the presented information correctly and to interpret it correctly.

However, there are also significant difficulties in expert research and attribution: restoration layers which make it difficult to install the author's handwriting; the need to confirm the ownership of the work by a certain artist or copied works. There is also a large number of falsifications of famous or lost originals, and the authorship of lesser-known artists is difficult to confirm due to the poor preservation or absence of their works in museum collections, as well as the lack of sufficiently convincing evidence in literary and archival sources. 
As a result, the conclusions drawn based on the assessment of the results of the study may be as follows: a categorical positive or negative; a probable positive or negative; a conclusion that the matter cannot be resolved. Insufficient information and lack of systematization can lead to the inability to determine the name of the wizard, as well as to erroneous attribution.

The complex method of research, which combines the results of technological, stylistic analysis with a thorough study of literary and archival sources, as a rule, gives the most complete solution to the questions posed to the art critic expert. The wording of the conclusions should be clear, complete, specific, non-double-digit interpretations.

\section{References:}

1. Новікова К. В., Міщенко І. І. Методика мистецтвознавчої експертизи (загальна частина). Київ : ДНДЕКЦ МВС України, 2019. 73 с.

2. История бумаги и бумажного производства : учеб. пособ. и хрестом. Санкт-Петербург : ГТУРП, 2011. $52 \mathrm{c.}$

3. Цитович В. И. Экспресс-метод исследования произведений станковой живописи в инфракрасной области спектра с применением видеосистемы VHS/. Экспертиза и атрибуциия произведений изобразительного искусства : матер. III научн. конф., Москва, 25-27 нояб. 1997 г. / под ред. В. А. Ворошень. Москва : Магнум АРС, 1998. C. $194-198$.

4. Косолапов А. И. Естественнонаучные методы в экспертизе произведений искусства / Государственный Эрмитаж. Изд. 2-е, перер. и доп. Санкт-Петербург : Изд-во Гос. Эрмитажа, 2015. 222 с. : ил.

5. Косолапов А. И. Физические методы изучения произведений искусства. Москва : Искусство, 1985. 192 с. : ил. 